\title{
Fuente Charfolé, J. L. de la (2019). La música en la catedral de Cuenca hasta el reinado de Carlos II. Contribución para una historia crítica. Madrid: Editorial Alpuerto, 370 pp. ISBN: 978-84-381-0514-6
}

La implicación del profesor e investigador José Luis de la Fuente Charfolé en el proyecto editorial denominado Investigación y Patrimonio musical, colaboración promovida desde la dirección del Centro de Investigación y Documentación Musical de la Universidad de Castilla-La Mancha (CIDoM), Unidad Asociada al CSIC, y la Editorial Alpuerto, ha posibilitado que desde el año 2012 hayan ido apareciendo una serie de monografías -y colaboraciones en obras colectivas- relacionadas con el riquísimo patrimonio y amplio fondo musical de la catedral de Cuenca (España). Los trabajos previos de este autor incluyeron los primeros cuatro volúmenes de las obras completas del maestro de capilla Alonso Xuárez entre los años 2013 y 2018, como también el estudio y edición crítica en de un "fascistolillo" anónimo, en 2017, que contenía salmos e himnos de Juan Navarro y Juan de Palestrina, así como de otros maestros conquenses del Renacimiento.

Este nuevo título aparece con el número 11 de la que ha pasado a ser, según un informe del grupo Investigación sobre el Libro Académico del Consejo Superior de Investigaciones Científicas (ILIA), cuyos resultados han sido incluidos en el Scholarly Publishers Indicators (SPI), una de las colecciones académicas de Bellas Artes más prestigiosas en España.

La lectura es muy sugestiva y verifica que las frases que el editor incluye en la contraportada del volumen son un registro fiel de su contenido. Dos pensamientos resumen a la perfección un texto que según el subtítulo (Contribución para una bistoria crítica) nace -así lo esperamos y deseamos- sin solución de continuidad. Sin duda se trata de una "apasionante secuencia de sucesos musicales" que hace entendible "un entramado de acontecimientos históricos y culturales sólidamente documentado". Cabe añadir que tanto los hechos como sus protagonistas quedaban sometidos a la liturgia: auténtica conditio sine qua non y razón de ser de todas las manifestaciones vinculadas con lo artístico en el ámbito sacro catedralicio.

El contenido ha sido estructurado por el autor en "reinados", en lugar de la habitual división en épocas a la que estamos acostumbrados. La acotación en seis capítulos permite definir con precisión la distribución de los diferentes magisterios de capilla y los principales acontecimientos vinculados con el reinado Habsbúrgico. 
Tras una introducción en la que se establece el status quaestionis musical y el contexto en el que se inscribe esta publicación, el Capítulo I, titulado De la Edad Media a los Reyes Católicos, aporta una detallada y cronológica nómina de los maestros, organistas y cantores que tuvieron relación con la catedral de Cuenca, algunos de la importancia del maestro del Papa Benedicto XIII, Giraldo Giráldez, del cantor del Rey Alfonso V, Juan del Mas, o del maestro francés Juan de Forteville. La constatación documental de la práctica polifónica en la catedral conquense a finales del siglo XV cierra un tiempo especialmente escaso en datos musicales, complejo por las bajas sufridas en las ya reducidas plantillas motivadas por la aparición de las epidemias de cólera y peste que asolaron la ciudad en la última década del siglo.

El Capítulo II aborda los acontecimientos ocurridos entre los magisterios de Francisco Tostado (1516) con cierre en Andrés López (1556), coincidente con el reinado de Carlos I. El autor pone en relieve el papel fundamental del coro como espacio litúrgicomusical con pruebas de su ubicación inicial en la cabecera del templo. En relación con los músicos señalar el asentamiento en el templo conquense de los ministriles del Duque del Infantado.

El capítulo III, Reinado de Felipe II, comienza con el estudio de la capilla de música desde el magisterio interino de Juan de Olivares, pasando por Gabriel Gálvez y Ginés de Boluda hasta Juan de la Peña. En este capítulo el autor continúa analizando las modificaciones sufridas en el coro como espacio arquitectónico, y los actos musicales que tuvieron lugar en la ciudad tanto durante la visita del monarca en 1564, como en sus exequias de 1598.

La parte nuclear, mucho más compleja en cuanto a relación y documentación histórica, corresponde a los Capítulos IV y V (reinados de Felipe III y Felipe IV). Los diferentes magisterios delimitan más de medio siglo de sucesos: entre el maestro Alonso Puro (1597) hasta el final de José de Alcalá (1663) se imbrica un periodo muy estable y musicalmente fecundo de más de treinta y dos años correspondiente a la etapa del maestro Juan de Castro y Mallagaray, discípulo del maestro de capilla de Felipe II, el flamenco Felipe Rogier.

El Capitulo VI y último del libro se circunscribe al reinado de Carlos II, coincidente con el compositor toledano Alonso Xuárez, discípulo de Tomás Micieces y maestro en las catedrales de Sevilla y Cuenca, instructor de músicos tan relevantes como Sebastián y Diego Durón. En el texto se ponen de relieve antecedentes y detalles inéditos del funcionamiento de la capilla de música hasta la muerte del maestro en 1696. Cierra el libro con un epílogo referido al periodo de transición continuista con que el Cabildo cierra el siglo con la provisión del magisterio en la figura de Julián Martínez Díaz, a la sazón discípulo de Alonso Xuárez.

Las imágenes que contiene la monografía, en escala de grises, son mejorables en tamaño y calidad, si bien esta mejora corresponde al editor y no al autor. La obra es coronada con dos herramientas notables: a una excelente ordenación bibliográfica, actualizada y rigurosa, sigue un índice onomástico siempre útil. 


\section{RESEÑAS DE LIBROS}

El lector interesado tendrá en su mano la capacidad para conocer los detalles y el contexto de unos hombres que desempeñando sus oficios musicales consiguieron mantener una actividad compleja en tiempos poco amables dejando tras de sí una huella profunda a la vez que mayormente desconocida.

\section{María Dolores Segarra Muñoz}

Universidad de Castilla-La Mancha Centro de Investigación y Documentación Musical (CIDoM)-Unidad Asociada al CSIC ORCID iD: https://orcid.org/0000-0002-4103-0981 